\title{
JOANNA USAKIEWICZ
}

(Białystok)

\section{ELENA LUCREZIA CORNARO PISCOPIA (1646-1684) PIERWSZA KOBIETA PHILOSOPHIAE MAGISTRA ET DOCTRIX}

Siedemnaste stulecie dało początek wielkim nowożytnym systemom filozoficznym, przyczyniło się do rozwoju nauk szczegółowych, pozwoliło rozkwitać myśli politycznej i społecznej. To również w wieku XVII po raz pierwszy w dziejach nowożytnej Europy kobieta otrzymała uniwersytecki stopień doktora filozofii, spełniajacc wszelkie wymogi natury merytorycznej i formalnej. Kobietą tą była Wenecjanka Elena Lucrezia Cornaro Piscopia. Jej sylwetkę chcemy tu przedstawić ${ }^{1}$.

Wybór drogi życiowej przez Elenę Lucrezię Cornaro Piscopię, tak nieoczywisty w sytuacji społecznej XVII wieku, był związany nie tylko z jej predyspozycjami intelektualnymi, ale szczególnie z rodziną, z której pochodziła, a która jej umożliwiła, a nawet, mówiąc nieco kolokwialnie, pchnęła ją w kierunku studiów uniwersyteckich. Rodzina Cornaro Piscopia od wieków związana była z Republiką Wenecką. Jej członkowie uczestniczyli w życiu ekonomicznym, politycznym i religijnym państwa, przysparzając zarówno jemu, jak i sobie bogactw i honorów. Ojciec Eleny Lucrezii, Giovanni Batista Cornaro Piscopia, osiagną̧ stanowisko jednego z Prokuratorów Świętego Marka. Był to najwyższy po doży urząd wenecki, którego głównym zadaniem była opieka nad bazyliką i innymi obiektami

\footnotetext{
1 Biografię Eleny Lucrezii Cornaro Piscopii opisujemy, opierając się na następujących źródłach: M. Deza, Vita di Helena Lucretia Cornara Piscopia, Per Antonio Bosio, Wenecja 1686; Wstęp wydawcy do Helenae Lucretiae (Quae et Scholastica) Corneliae Piscopiae Virginis pietate et eruditione admirabilis; Ordini D. Benedicti privatis votis adscriptae Opera, quae quidem haberi potuerunt, ed. B. Bacchinus, Typis Hippolyti Rosati, Parma 1688, s. 1 i n. (dalej cytowane jako Helenae Lucretiae Piscopiae Opera); A. Lupis, L'Eroina Veneta Ouero la Vita di Elena Lucretia Cornara Piscopia, Per il Curti, Wenecja 1689 oraz F.L. Maschietto, Elena Lucrezia Cornaro Piscopia (1646-1684). The First Woman in the World to Earn a University Degree, Saint Joseph's University Press, Filadelfia 2006.
} 
sakralnymi w Wenecji. Matka, Zanetta Boni, pochodziła zaś z niższej klasy społecznej. Rodzice pozostawali w nieformalnym związku do 1654 roku, gdy wzięli ślub, mając już kilkoro dzieci, wśród nich Elenę Lucrezię, która przyszła na świat 5 czerwca 1646 roku.

W rodzinie Cornaro Piscopia panowała zawsze miłość do sztuki i nauki. Przodkowie Giovanniego Battisty zebrali kolekcję obrazów, wśród nich dzieła Tycjana, ale przede wszystkim zgromadzili wspaniały księgozbiór, który Giovanni Battista jeszcze powiększył. W bibliotece znajdowały się greckie i łacińskie manuskrypty, prace historyczne, matematyczne i filozoficzne, a wśród tych ostatnich kilka wydań Arystotelesa, dzieła Platona, Plutarcha, Porfiriusza, Cicerona i Seneki. Wszystkie te książki dostępne były dla Eleny Lucrezii już od najmłodszych jej lat. Giovanni Battista wspierał i zapraszał do swego domu ludzi wykształconych, patronował też założonej w 1647 roku Accademia Veneziana dei Delfici, będącej rodzajem stowarzyszenia naukowo-kulturalnego, jakich w czasach nowożytnych wiele działało we włoskich miastach.

Pierwszy, poza rodzicami, na szczególne predyspozycje intelektualne Eleny Lucrezii zwrócił uwage przyjaciel rodziny, proboszcz parafii San Luca, ojciec Giovanni Battista Fabris (zm. 1668). To on zasugerował, aby rozpocząć jej kształcenie od nauczania języków klasycznych. Greki miał nauczać sam. Lekcje zaczęły się w 1653 roku, gdy Elena Lucrezia miała 7 lat, i trwały do śmierci Fabrisa w 1668 roku. Rozpoczęła też równolegle naukę łaciny u ojca Giovanniego Valier. Języka greckiego (klasycznego i nowożytnego) uczył ją następnie Alvise Gradenigo, należący do osiadłej w Wenecji greckiej kolonii, której początki sięgały XIII wieku. Oprócz języków klasycznych Elena Lucrezia uczyła się francuskiego i hiszpańskiego. Studiowała matematykę, nauki przyrodnicze, astronomię i geografię. Uczyła się też muzyki. Nie wiemy, na jakim instrumencie grała, ale jej nauczycielka Maddalena Capelli była organistką. Stała się ona zresztą bardzo bliska Elenie Lucrezii i towarzyszyła jej aż do śmierci przez blisko dwadzieścia lat najpierw w Wenecji, potem w Padwie. Jako ciekawostkę dodajmy, że znany kompozytor i organista wenecki, Carlo Grossi (ok. 1634-1688), zadedykował Elenie Lucrezii swój utwór wydany w 1663 roku pod tytułem Sacre ariose cantate a voce sola, dedicate all'Ellena Cornera Episcopia. Opera quarta di Carlo Grossi. Szczególnie jednak Elena Lucrezia rozwijała swoje zainteresowania filozofią i teologią. Gdy miała około 11 lat w jej rodzinnym domu pojawił się teolog ojciec Ippolito Marchetti (1590-1662). Został kapelanem rodziny. To on najprawdopodobniej uczył Elenę Lucrezię katechizmu, ale też podstaw filozofii i teologii, choć nie były to jeszcze metodyczne i uporządkowane studia.

W 1663 roku przybył do Wenecji jezuita ojciec Carlo Maurizio Vota (1629-1715), który również został nauczycielem Eleny Lucrezii i był nim aż do roku 1678, gdy otrzymała ona stopień doktora filozofii. Vota był człowiekiem 
niezwykle uzdolnionym, poliglotą, filozofem, a także dyplomatą. To on zaaranżował małżeństwo królewicza Jakuba, syna króla Jana III Sobieskiego, z hrabianką palatyńską Jadwigą Elżbietą, siostrą Karola III, szwagra cesarza Leopolda I, ratując tym samym sojusz Polski z Austrią. Vota uczył Elenę Lucrezię przede wszystkim matematyki i astronomii. Dzięki niemu mogła poznać myśl Galileusza (1564-1642) oraz Pierre'a Gassendiego (1592-1655), który jako astronom był zwolennikiem teorii Galileusza, a jako filozof znanym krytykiem arystotelizmu i propagatorem myśli Epikura.

Kolejnym nauczycielem Eleny Lucrezii był Carlo Rinaldini (1615-1698), wówczas profesor Uniwersytetu w Padwie, filozof i matematyk. Był on pod wpływem Gassendiego, przede wszystkim jego krytycznego stosunku do Arystotelesa. Pozostawił po sobie kilka dzieł, w większości poświęconych zagadnieniom matematycznym, na przykład Opus mathematicum (Bolonia 1655), De resolutione atque compositione mathematica libri duo (Padwa 1668), czy Geometra promotus (Padwa 1670).

Rinaldini i Elena Lucrezia poznali się w bibliotece jej ojca, gdy Rinaldini przeglądał prace Archimedesa. Jako nauczyciel zaszczepił w swojej uczennicy przekonanie, iż należy poznawać i badać zjawiska bezpośrednio, a nie przyjmować poglądy starożytnych myślicieli jako wyraz prawdy absolutnej. Rinaldini przygotowywał Elenę Lucrezię zgodnie z tokiem studiów Uniwersytetu w Padwie, prowadzącym do uzyskania stopnia doktora teologii. Szczególne zainteresowanie teologią wiązało się z wcześniej wyrażoną już przez Elenę Lucrezię chęcią wstąpienia do zakonu, czemu sprzeciwił się jej ojciec i to na jego polecenie miała się oddać studiom - właściwie to jego ambicje zaspokajała, starając się zdobyć stopnie naukowe. Jej pragnienie życia zakonnego spełniło się o tyle, że została benedyktyńską oblatką, ślubujacc czystość, ale pozostając przy rodzinie i żyjąc w świecie.

Nauczycielem teologii Eleny Lucrezii był franciszkanin Felice Rotondi (ok. 1630-1702). Rotondi, przyjaciel rodziny, nauczał teologii w swoim zakonie w Wenecji, był też profesorem teologii na Uniwersytecie w Padwie. Dał się poznać jako zwolennik skotyzmu z jego uwypukleniem wyższości miłości nad poznaniem, wiary nad rozumem, obowiązku moralnego i chrystocentryzmu. Autor między innymi Enchiridion dialecticum juxta Aristotelis Peripateticorum principia, et Scoti Doctoris Subtilis... (Padwa 1672) oraz Enchiridion rhetoricum sacrum et humanum... (Padwa 1672-1673). Studia teologiczne musiały opierać się na czytaniu Biblii; aby korzystać z oryginału, Elena Lucrezia uczyła się języka hebrajskiego. Zauważyć tu warto, że rozwijała swoje zainteresowania teologiczne w bardzo ważnym dla Kościoła Zachodniego okresie i w wielce specyficznym, jeżeli chodzi o stosunek do religii państwie europejskim. Są to czasy po Soborze Trydenckim (1545-1563), który odrzucając główne idee reformacji, wprowadzał zmiany w Kościele katolickim zarówno dotyczące wiary (nauka o usprawiedliwieniu, potę- 
pienie predestynacji i indywidualnego interpretowania Pisma Świętego, potwierdzenie znaczenia wszystkich siedmiu sakramentów, uporządkowanie kwestii odpustów i czci oddawanej świętym), jak dyscypliny kościelnej (między innymi: zachowanie celibatu księży, seminaria duchowne w każdej diecezji, indeks ksiąg zakazanych, który ogłoszono w 1559 roku). Sobór zapoczątkował również stopniowe wprowadzanie języków narodowych w czytaniach podczas nabożeństw. Zmiany zadekretowane postanowieniami Soboru wprowadzano nadal jeszcze w XVII wieku. Wenecja zaś zawsze była i pozostała za czasów Eleny Lucrezii państwem kosmopolitycznym i tolerancyjnym wobec różnych religii i wyznań. Rządzący Republiką często w historii dawali świadectwo, że stawiają wyżej dobro i korzyści swego państwa ponad nakazy Kościoła katolickiego, mimo że Wenecja była państwem katolickim.

Ojciec Rotondi zadowolony z osiągnięć swojej uczennicy, po konsultacji z Rinaldinim, wystąpił w 1677 roku do Uniwersytetu w Padwie o pozwolenie na przystąpienie Eleny Lucrezii do egzaminów w celu uzyskania stopnia doktora teologii. Istotnym potwierdzeniem jej wiedzy i umiejętności była obrona tez filozoficznych, która odbyła się 30 maja 1677 roku w obecności szerokiego grona zaproszonej arystokracji i uczonych, również z zagranicy. Elena Lucrezia miała wówczas zadziwić słuchaczy swoją wiedzą. Rotondi zwrócił się więc do Uniwersytetu w Padwie, ponieważ od XV wieku, gdy Padwa została przyjęta w poczet miast Republiki Weneckiej, stał się on „uniwersytetem weneckim” dotowanym przez władze. Choć padewscy profesorowie, skonsultowawszy się z innymi uniwersytetami (między innymi w Paryżu i Louvain), wyrazili zgodę, aby rozpoczęto przygotowania do postępowania doktorskiego, sprzeciwił się temu kardynał Gregorio Barbarigo (1625-1697), ówczesny biskup Padwy i kanclerz Uniwersytetu. Swoją odmowę umotywował tym, że choć kobieta może uczyć się teologii, nie może jej publicznie nauczać. Wydaje się, że jego postawa nie tylko wynikała z tradycyjnego zakazu nauczania kobiet w Kościele, opierającego się na nauce św. Pawła (1Tm 2, 12), ale wiązała się również z kontrreformacją, skłaniającą się ku rygorystycznemu nauczaniu doktryny katolickiej i przestrzeganiu nakazów Kościoła ${ }^{2}$. Ponieważ przebywał wówczas w Rzymie, doszło do wymiany listów między nim a ojcem Eleny Lucrezii, a w konsekwencji kardynał zgodził się, aby dopuszczono ją do starania się o stopień doktora filozofii.

22 czerwca 1678 roku Rinaldini zwrócił się do przedstawicieli Kolegium Filozofów i Lekarzy Uniwersytetu w Padwie o dopuszczenie Eleny Lucrezii Cornaro Piscopii do egzaminu z filozofii, na co się zgodzono. Następnego dnia w obec-

2 Por. F.L. Maschietto, Elena Lucrezia Cornaro Piscopia (1646-1684). The First Woman in the World to Earn a University Degree, wyd. cyt., s. 70. 
ności dwóch świadków wyznała ona swoją wiarę, potwierdzając se esse catholicam et bonam christifidelem. 24 czerwca 1678 roku wybrano dwa fragmenty z dzieł Arystotelesa, na podstawie których miała przygotować się do egzaminu. Były to fragmenty z Analityk wtórych (1, 2, 71b) oraz z Fizyki (1, 5, 189a). Pierwszy z nich przedstawia definicję dowodu, którego wniosek tworzy wiedzę naukową, wskazując jednocześnie na różnicę między takim dowodem a sylogizmem. Drugi fragment zawiera definicję zasad jako pierwotnych, niewywodzących się z samych siebie, ani z czegoś innego, a będących tym, z czego wywodzi się wszystko inne; nadto we fragmencie tym jako zasady przedstawione zostały przeciwieństwa pierwotne. W dniu następnym odbyła się publiczna dyskusja. Elena Lucrezia tak wspaniale się zaprezentowała, że przez aklamację przyznano jej stopień doktora filozofii ( $p h i$ losophiae magistra et doctrix), choć zwykłą procedurą było tajne głosowanie. Na potwierdzenie tego osiągnięcia wręczono jej następujące symbole: książkę jako dla nauczycielki, pierścień jako dla zwyciężczyni w dyspucie filozoficznej, gronostajową pelerynę jako dla doktora oraz wieniec laurowy - symbol triumfu. Insygnia te wręczył jej Rinaldini. W lipcu tego samego roku uroczyście została przyjęta do grona Kolegium Filozofów i Lekarzy Uniwersytetu w Padwie z wszystkimi przywilejami i obowiązkami. Uczestniczyła między innymi w kolejnych nadaniach stopnia doktora.

Elena Lucrezia zamieszkała w należącym do rodziny domu w Padwie, gdzie oddawała się dalszym studiom coraz częściej utrudnianym jednak przez rozmaite dolegliwości, jak to określił wydawca jej pism, Benedetto Bacchini (1651-1721), przez „Illias morborum” ( "Iliadę chorób”) ${ }^{3}$, a były to: szkorbut, atak pęcherzyka żółciowego, tak zwana „czerwona gorączka”, której towarzyszyły pojawiające się na całym ciele pęcherze, kamica nerkowa, a u kresu życia także drgawki i skurcze mięśni. Elena Lucrezia zmarła 26 lipca 1684 roku i została pochowana z należnymi honorami.

Pozostały tylko nieliczne jej pisma, ponieważ sama zadecydowała, aby po jej śmierci zniszczyć jej archiwum, co też uczyniono. Zachowały się więc tylko te, które pozostawały w rękach osób prywatnych lub instytucji. Znakomitą większość z nich wydał w 1688 roku wspomniany już Benedetto Bacchini jako Helenae Lucretiae (Quae et Scholastica) Corneliae Piscopiae Virginis pietate et eruditione admirabilis; Ordini D. Benedicti privatis votis adscriptae Opera, quae quidem haberi potuerunt. Dokładny wykaz całości spuścizny po Elenie Lucrezii współcześnie przedstawił Francesco Ludovico Maschietto w monografii jej poświęconej ${ }^{4}$. Wymienił on następujące pisma i utwory poetyckie:

3 Helenae Lucretiae Corneliae Piscopiae Opera s. 33.

4 Zob. F.L. Maschietto, Elena Lucrezia Cornaro Piscopia (1646-1684). The First Woman in the World to Earn a University Degree, wyd. cyt., s. 93. 
- jeden przekład,

- cztery mowy akademickie napisane w jezzyku włoskim,

- trzydzieści listów po łacinie i po włosku,

- dwie petycje do papieża,

- jedenaście elogiów w różnych językach,

- pięć epigramatów po łacinie i po grecku,

- akrostych w języku francuskim,

- sześć sonetów w różnych językach,

- jedną odę w języku włoskim.

Przekład, który został wymieniony jako pierwszy, był też pierwszą publikacją drukiem Eleny Lucrezii Cornaro Piscopii, wydaną w Wenecji w 1669 roku pod tytułem Lettera overo colloquio di Christo Nostro Redentore all'anima devota, composta dal R.P.D. Giovanni Laspergio Cartusiano in Lingua Spagnuola, e portata nell'Italiana, dall'Illustrissima Signora Elena Lucretia Cornara Piscopia... ${ }^{5}$ Jest to tłumaczenie z języka hiszpańskiego na język włoski dzieła poświęconego ascezie autorstwa kartuzjańskiego mnicha Giovanniego Lanspergio (1489-1539), napisanego $\mathrm{w}$ formie listu Jezusa do duszy pragnącej być Mu wierną i stawać się doskonałą.

W tym ubóstwie spuścizny to mowy, z których trzy zostały opublikowane ${ }^{6}$, pozwalają dowiedzieć się najwięcej zarówno o sposobie pisania, jak i poglądach autorki. Mowa zatytułowana In lode della serenissima Republica e città di Venezia ( Na pochwałę najjaśniejszej Republiki i miasta Wenecji ${ }^{7}$ napisana została z okazji przyjęcia Eleny Lucrezii Cornaro Piscopii do Accademia dei Pacifici w Wenecji. Na początku mowy autorka opisuje w nieco sentymentalnych słowach miłość do ojczyzny, odwołując się do przykładów ze starożytnej literatury i historii. Czyny bohaterów i wydarzenia z historii starożytnej Grecji i Rzymu także w dalszej części tej mowy (jak i w pozostałych mowach) służą do egzemplifikacji postaw zarówno uważanych przez Elenę Lucrezię Cornaro Piscopię za właściwe, jak i ocenianych przez nią jako godne potępienia. Następnie autorka zastanawia się nad postawami obywateli w czasie wojny i pokoju, koncentrując się na problemie, czy zbytek i luksus mogą zaszkodzić państwu. Odnosząc się do Wenecji, wyraźnie wskazuje, że „moja Ojczyzna jaśnieje sławą nie mniej dzięki radzie swoich senatorów niż dzięki cnocie generałów" 8 . Jej obywatele potrafią, gdy zachodzi taka potrzeba,

\footnotetext{
5 Przekład ten odnajdziemy też w: Helenae Lucretiae Corneliae Piscopiae Opera, s. 179 i n.

6 Zob. tamże, s. 51-106. Jedna z mów dotąd jeszcze nie została opublikowana.

7 W wydaniu Helenae Lucretiae Corneliae Piscopiae Opera jest to Discorso primo - Mowa pierwsza.

8 „.... la mia Patria risplenda gloriosa, non meno per lo Consiglio de suoi Senatori, che per lo Valore de Generali"; tamże, s. 55 (wszystkie przekłady, o ile inaczej nie podano, autorki artykułu).
} 
zostawić „(...) cierpienia Marsa dla rozkoszy Wenus, lub powściągliwość Muz dla podniet Bogini Łakomstwa" 9. Wybierają zawsze zachowania odpowiednie do sytuacji: wojna - pokój, praca - odpoczynek. Rządzący zaś Republiką wiedzą, że władza nie powinna opierać się wyłącznie na sile oręża, ale że niezmiernie istotne są dobre prawa. Elena Lucrezia Cornaro Piscopia odwołuje się do cnoty umiarkowania (la temperanza), sprawiedliwości (la giustizia) i roztropności (la prudenza), które ujawniają się odpowiednio do okoliczności i osoby. To cnoty żołnierskie i mądrość polityczna uczyniły z Wenecji wspaniałą republikę. W swych rozważaniach najczęściej powołuje się wprost i nie wprost na Arystotelesa. Widoczne jest podkreślanie zasady „złotego środka”, umiaru, odpowiedniości, każdemu „,to, co mu się słusznie należy" ${ }^{10}$.

Dwie kolejne mowy nie mają w tytule sprecyzowanego tematu, a tylko ogóle wskazanie: un problema politico (,problem polityczny") ${ }^{11}$. Pierwszą z nich Elena Lucrezia Cornaro Piscopia przedstawiła, gdy w 1670 roku zaczęła przewodzić Accademia dei Pacifici. W mowie tej wskazuje między innymi, że ten, kto pragnie sprawować władzę, musi rozważyć, czy jest w stanie podołać wynikającym z niej obowiązkom. Zauważa, że w jej czasach żyją mężczyźni gotowi poświęcić honor w imię posiadania władzy i tylko nieliczni w wyścigu do władzy wiedzą, jak się przygotować, jak postepować, aby ich rządy stały się godne pochwały. To również do sprawujących władzę odnosi się według Eleny Lucrezii Cornaro Piscopii znane od starożytności powiedzenie: „a jednakże nie każde drewno stanie się wielbionym jako posąg Merkurego" 12. Rządzenie jest sztuką, która opiera się przede wszystkim na doświadczeniu. Jako główny problem zostaje postawione w mowie pytanie, czy sława dobrze rządzącego opiera się na jego rzeczywistej zdolności do rządzenia, czy raczej powstaje w kontraście do niezdolności jego następców. Elena Lucrezia opisuje w tym kontekście między innymi siebie jako następczynię Francesca Marii Santinelliego w przewodzeniu Akademią. Ukazuje go jako wzór cnót moralnych, uwypuklając to poprzez zestawienie z opisem siebie jako osoby wielce niedoskonałej - pełnej imperfezzioni („wad” czy „niedoskonałości”) ${ }^{13}$. F.L. Maschietto uważa, że nie jest to tylko zabieg retoryczny, ale „,szczere przekonanie jej

9, ,...) i patimenti di Marte per le delizie delle Veneri, o la parsimonia delle Muse per gl'incitamenti della Dea Gola"; tamże, s. 54-55.

10 Arystoteles, Polityka, 1329a. Przekład na język polski za: Arystoteles, Dziela wszystkie, tłum. zbiorowe, Wydawnictwo Naukowe PWN, Warszawa 1990-1994, t. 6, s. 196.

11 W wydaniu Helenae Lucretiae Corneliae Piscopiae Opera są to: Discorso secundo (Mowa druga) oraz Discorso terzo (Mowa trzecia).

$12,(. .$.$) e benche ogni legno non è atto per esser adorato sotto figura di Mercurio"; tamże,$ s. 76 .

13 Tamże, s. 86. 
szlachetnej duszy" 14, a przemawiać za tym ma jej postawa życiowa i treść innych zachowanych pism.

Kolejna mowa także została napisana dla Accademia dei Pacifici. Jej myśl przewodnia to wskazanie na istnienie „niezgodnej zgodności” (una discorde concordia) ${ }^{15}$ zarówno w rzeczach zmysłowych, jak i niezmysłowych. Autorka marginalizując świat przyrody ożywionej i nieożywionej, koncentruje się na przykładzie ludzkiego ciała jako harmonijnej całości złożonej z różniących się od siebie części. Opisuje anatomię człowieka, jego poszczególne członki i organy, które tak rozmaite i różne od siebie, jako całość są „,strukturą tak zrównoważoną i doskonałą” 16. Jako przykłady niezgodnej zgodności podaje również muzykę, w której harmonię osiąga się grając na różnych instrumentach, śpiewając rozmaitymi głosami, wprowadzając różne tempa. Również planety i gwiazdy, odznaczające się rozmaitą wielkością i ruchem, stanowią jedną doskonałą całość. Niezgodną zgodność odnajduje też na polu teologii, a jest to Trójca Święta złożona z trzech różnych Osób Boskich. Tak więc zgodność całego świata opiera się na niezgodności jego elementów. W mowie tej został też przedstawiony problem, czy dowódca wojska, aby uciszyć bunt wśród żołnierzy, powinien użyć wobec nich kar, czy raczej być umiarkowanym i wyrozumiałym. Sądzenie innych jak, odwołując się do Arystotelesa, twierdzi Elena Lucrezia Cornaro Piscopia, jest tyleż trudne, co konieczne. Dowódca powinien wiedzieć, kiedy posłużyć się groźbami i karami, a kiedy ich zaniechać i okazać się wyrozumiałym. To, co jest gniewem u innych ludzi, u tych, którzy mają władzę, łatwo staje się okrucieństwem. Konieczna jest więc roztropność. Autorka odwołuje się do przykładu zachowania wobec zagrożenia dwóch zwierząt: jeżozwierza i słonia. Jeżozwierz broni się, podnosząc z natury posiadane kolce, słoń zaś flegmatycznie potrząsa swoim ciałem. W mowie tej Elena Lucrezia Cornaro Piscopia deklaruje swoją lojalność wobec Wenecji - „Republiki, gdzie sprawiedliwość wzrastała zawsze z mlekiem roztropności jako jej siostra bliźniacza" ${ }^{17}$.

Czwarta mowa, jak już wspomnieliśmy, nigdy nie została opublikowana, a była napisana z okazji przyjęcia Eleny Lucrezii do Accademia degli Infecondi w Rzymie ${ }^{18}$. W tekście tym z wielką pokorą mówi o sobie i ocenia swoje wypowiedzi, jednocześnie wychwalając Akademię.

$14,(\ldots)$ the sincere convictions of her noble soul”; F.L. Maschietto, Elena Lucrezia Cornaro Piscopia (1646-1684). The First Woman in the World to Earn a University Degree, wyd. cyt., s. 94.

15 Helenae Lucretiae Corneliae Piscopiae Opera, s. 90.

16, „...) una fattura cosi temperata e perfecta”; tamże s. 92.

17, ,...) una Republica, che Gemella della Giustizia, crebbe sempre col latte della prudenza"; tamże, s. 100.

18 Wiadomości na temat treści tej mowy zaczerpnięte zostały z: F.L. Maschietto, Elena Lucrezia Cornaro Piscopia (1646-1684). The First Woman in the World to Earn a University Degree, wyd. cyt., s. 95-96. 
Przejdziemy teraz do zachowanych listów pióra Eleny Lucrezii ${ }^{19}$. Jest to korespondencja do różnych osób zarówno znanych i wpływowych, jak i prywatnych, w wielu wypadkach czysto kurtuazyjna. Najwięcej, a mianowicie trzynaście, zachowało się listów napisanych przez Elenę Lucrezię Cornaro Piscopię do kardynała Francesca Barberiniego (1597-1679), przebywającego w Rzymie; nie zostały one wydane. Dotyczą spraw rodzinnych lub osób objętych przez Elenę Lucrezię opieką, zarówno duchownych, jak i świeckich. Znamy też treść trzech listów napisanych do ojca ${ }^{20}$, gdy między lipcem a sierpniem 1680 roku przebywała w Padwie. Informuje w nich o swoim zdrowiu i studiach, wyraża też radość z ciąży siostry. Dwa zachowane listy związane są z osobą jednego z jej nauczycieli, Rinaldiniego. Jeden z nich jest adresowany do niego; Elena Lucrezia prosi w nim, aby Rinaldini wrócił do Wenecji, by dalej ją uczyć. W drugim, którego adresatem jest kardynał Emmanuel Théodore de La Tour d'Auvergne Bouillon (1643-1715) 21, zawiadamia o wysłaniu pierwszego tomu dzieł filozoficznych Rinaldiniego, zachwalając jego erudycję i staranność.

Wspomniane w wykazie zachowanych pism Eleny Lucrezii Cornaro Piscopii dwie petycje do papieża skierowane były do Klemensa X. Zostały wysłane w 1670 i 1674 roku. Obie zawierają prośbę o pozwolenie na kilka wizyt w klasztorach weneckich, między innymi w klasztorze św. Mateusza na wyspie Murano, gdzie żyła jako mniszka siostra Eleny Lucrezii. Papież pozwoleń udzielił.

Przeglądając znane nam utwory poetyckie Eleny Lucrezii Cornaro Piscopii, warto zatrzymać się na elogiach i odzie. Elogium wywodzi się ze starożytnego Rzymu, gdzie określano tym mianem napisy pochwalne umieszczane na wizerunkach przodków i pomnikach. W czasach nowożytnych elogium nazywano mowy pochwalne wygłaszane na przykład w akademiach. Elogia Eleny Lucrezii maja charakter panegiryczny, skierowane są do osób żyjących, zarówno do władców i osób znanych, jak i zwykłych znajomych. Wśród elogiów zwracają uwagę swoim entuzjazmem utwory związane ze zwycięstwem chrześcijańskiej Europy nad Turkami $^{22}$. Zostały one napisane dla cesarza Leopolda I (1640-1705), księcia lotaryńskiego Karola V (1643-90) oraz króla polskiego Jana III Sobieskiego (1629-1696). W elogium wychwalającym tego ostatniego, Elena Lucrezia pisze, że zwyciężył turecką hydrę jak Herkules, że większy jest nawet od Cezara, a na zakończenie nazywa go Christianae religionis propugnator („obrońcą wiary chrześcijań-

19 Zachowały się też listy pisane do niej, na przykład z podziękowaniem za elogium Jana III Sobieskiego (zob. Helenae Lucretiae Corneliae Piscopiae Opera, s. 141) czy Charlesa Catona de Court (1654-1694), francuskiego prawnika i znawcy języków klasycznych (zob. tamże, s. 163-171).

20 Zob. tamże, s. 151-156.

21 Zob. tamże, s. 143-145.

22 Zob. tamże, s. 118-131. W wydaniu tym opublikowano sześć elogiów. 
skiej") ${ }^{23}$. Wykaz pism Eleny Lucrezii Cornaro Piscopii zamyka oda datowana na rok 1680. Utwór bardzo osobisty ku czci Chrystusa ukrzyżowanego za grzechy ludzi został odnaleziony po śmierci Eleny Lucrezii przez jej brata Girolamo (ok. 1657-1734) i podarowany Luisie Bergalli, która go opublikowała ${ }^{24}$ wraz z notką o autorce, w której podkreślone zostały jej talenty, zainteresowania filozoficzne i znajomość języków ${ }^{25}$.

Epigramaty, akrostych i sonety odnajdziemy w różnych zbiorowych wydaniach. Wszystkie epigramaty miały charakter panegiryczny i wychwalały konkretne osoby: dwa Giovanniego Cornaro, dowódcę Friuli, który zasłynął, zapobiegając rozprzestrzenieniu się w tym regionie zarazy; jeden Angelo Sumachiego greckiego nobila - dla uhonorowania jego doktoratu z medycyny; dwa Józefa Ignacego (1678-1711), syna cesarza Leopolda I, późniejszego Józefa I, w związku z jego narodzinami. Zostały one opublikowane odpowiednio w następujących książkach: A. Dragoni, Oratione di A. D. componimenti d'altri soggetti in lode di Giovanni Cornaro, luogotenente della patria del Friuli (Undine 1683); Epantismatologia overo raccoglimento poetica de più forti igegni nella solenne coronatione in filosofia e medicina del signor Angelo Sumachi nob. di Zante (Padwa 1668); Compositioni degli accademici Ricovrati per la morte della nobile donna signora Elena Lucrezia Cornaro Piscopia dedicate all'Eccellenza del signor Gianbattista suo padre procuratore di S. Marco dal conte Alessandro abb. De Lazzara principe dell' Accademia (Padwa 1684). W poświęconej znanemu jezuicie Ojcu Giacomo Lubraniemu (1619-1693) publikacji zatytułowanej: Seconda Corona intrecciata da varii Litterati co'fiori de'loro ingegni... (Wenecja 1675), a wydanej przez Elenę Lucrezię Cornaro Piscopię, wśród około pięćdziesięciu utworów znajdują się także sonety i elogia jej autorstwa. Wymieniony akrostych, który miał charakter gratulacyjny, a jego adresatem był król Francji Ludwik XIV, został dostrzeżony i opublikowany przez królewskiego historyka Claude'a Charlesa Guyonnet de Vertron w dziele La nouvelle Pandore ou les femmes illustres du siècle de Louis le Grand (Paryż 1698).

O tym, że mogło być dużo więcej prac Eleny Lucrezii, można wnioskować ze słów zawartych w dziele znanym jako Iter Italicus ${ }^{26}$ benedyktyna Jeana Mabillon (1632-1707), francuskiego historyka, który podróżując po ziemiach włoskich, czy-

\footnotetext{
23 Tamże, s. 127.

24 Zob. Componimenti poetrici delle piu' illustri rimatrici d'ogni secolo raccolti da Luisa Bergalli, Apresso Antonio Mora, Wenecja 1726, t. 2, s. 169.

25 Zob. tamże, t. 2, s. 280-281.

26 Tytuł właściwy brzmi: Museum italicum seu collectio veterum scriptorum ex bibliothecis italicis eruta a d. Johanne Mabillon et d. Michaele Germain (Apud Viduam Edmundi Martin, Johannem Boudot, Stephanum Martin, Paryż 1687).
} 
nił kwerendy w tamtejszych bibliotekach i archiwach. Pisze on, że gdy przebywał w Wenecji, został zaproszony do domu Cornaro przez ojca clarissimae nostri saeculi heroine ${ }^{27}$ i widział w tamtejszej bibliotece bardzo wiele (permulta) różnego rodzaju i w różnych językach jej pism.

W zachowanych pismach przede wszystkim zwraca uwage częste odwoływanie się do autorów klasycznych, zarówno poprzez bezpośrednie cytaty, jak i nawiązania. Elena Lucrezia Cornaro Piscopia przywołuje poetów, historyków i filozofów. Gdybyśmy na tej podstawie chcieli zrekonstruować kanon autorów jej lektur (a wiemy, że miała dostęp do nich w ojcowskiej bibliotece), to byłaby to bardzo długa lista. Wymienimy tylko tych, do których w swych pracach sięgała wielokrotnie. Z filozofów są to: Arystoteles (którego niewątpliwie odnajdziemy najczęściej, zwłaszcza zaś jego Politykę), Platon, Seneka, Demokryt, Pitagoras oraz ojcowie Kościoła - św. Ambroży, Jan Chryzostom, św. Bazylii. Przywołuje utwory Homera, Sofoklesa, Owidiusza i Horacego, a także prace Salustiusza, Pliniusza i Kasjodora. Niezwykłej erudycji dowodzą też podawane przez nią przykłady postaci i wydarzeń historycznych i tu znowu na plan pierwszy wysuwają się czasy starożytnej Grecji i Rzymu, ale nie obce są jej też dzieje Bizancjum i oczywiście własnej ojczyzny.

Jaki obraz Eleny Lucrezii Cornaro Piscopii dają nam jej zachowane pisma? Wyraźnie wyłania się z nich dobra chrześcijanka i dobra Wenecjanka, za jaką z pewnością chciała uchodzić. Jej religijność i wierność Kościołowi katolickiemu miały swój wyraz zarówno w jej życiu prywatnym, jak i publicznym. Ich przejawem jest oczywiście spełnione pragnienie życia konsekrowanego, ale także posłuszeństwo we wszystkim ojcu. Publicznie swoją wiarę wyraziła na przykład wspomnianymi elogiami na cześć obrońców chrześcijaństwa pod Wiedniem. Miłość do ojczyzny zaś jest wyraźną dominantą jej mów. Republika Wenecka jest w nich ukazana jako państwo o ustroju doskonałym - spełnienie wizji przekazanych przez starożytnych filozofów. Nie możemy też nie wspomnieć tu jeszcze raz o wykształceniu i erudycji Eleny Lucrezii Cornaro Piscopii, stanowi to bowiem o jej wyjątkowości, zwłaszcza w czasach, w których żyła. Była wszak kobietą, która dotrzymywała pola w dyskusji profesorom uniwersyteckim, która pisząc, odwoływała się do wielkiego korpusu dzieł zwłaszcza autorów starożytnych, która znakomicie poznała i umiała zinterpretować wydarzenia historyczne. I na tym zakończmy ten szkic do portretu kobiety wykształconej, pierwszej doktor filozofii w nowożytnej Europie.

27 „Najsławniejszej heroiny naszego wieku”; tamże, t. 1, s. 35. 


\section{ELENA LUCREZIA CORNARO PISCOPIA (1646-1684) - THE FIRST WOMAN PHILOSOPHIAE MAGISTRA ET DOCTRIX}

\section{Summary}

The article presents the short biography and works of Venetian woman - Elena Lucrezia Cornaro Piscopia, the first woman in history, who received doctoral degree in philosophy. It took place in 1678 on the University of Padua - "the Venetian University" since the fifteenth century. Elena Lucrezia Cornaro Piscopia was very well educated, especially in philosophy and theology. She also knew several languages: Latin, Greek, Spanish, Hebrew. Only part of her writings is kept, among which the most important are the four discourses on political problems.

Key words: Elena Lucrezia Cornaro Piscopia, the first woman Doctor of Philosophy, Venice

Słowa kluczowe: Elena Lucrezia Cornaro Piscopia, pierwsza kobieta doktor filozofii, Wenecja

\section{Bibliografia}

Arystoteles, Dzieła wszystkie, tłum. zbiorowe, Wydawnictwo Naukowe PWN, Warszawa 1990-1994, t. 1-6.

Componimenti poetrici delle piu' illustri rimatrici d'ogni secolo raccolti da Luisa Bergalli, Apresso Antonio Mora, Wenecja 1726.

Deza M., Vita di Helena Lucretia Cornara Piscopia, Per Antonio Bosio, Wenecja 1686.

Guyonnet de Vertron C.Ch., La nouvelle Pandore ou les femmes illustres du siècle de Louis le Grand, Chez la Veuve de Claude Mazuel, Paryż 1698.

Helenae Lucretiae (Quae et Scholastica) Corneliae Piscopiae Virginis pietate et eruditione admirabilis; Ordini D. Benedicti privatis votis adscriptae Opera, quae quidem haberi potuerunt, ed. B. Bacchinus, Typis Hippolyti Rosati, Parma 1688.

Lupis A., L'Eroina Veneta Ouero la Vita di Elena Lucretia Cornara Piscopia, Per il Curti, Wenecja 1689.

Maschietto F.L., Elena Lucrezia Cornaro Piscopia (1646-1684). The First Woman in the World to Earn a University Degree, Saint Joseph's University Press, Filadelfia 2006.

Museum italicum seu collectio veterum scriptorum ex bibliothecis italicis eruta a d. Johanne Mabillon et d. Michaele Germain, Apud Viduam Edmundi Martin, Johannem Boudot, Stephanum Martin, Paryż 1687.

Norwich J.J., Historia Wenecji, tłum. J. Bartoszewicz, Grupa Wydawnicza Foksal, Warszawa 2015. 
Seconda Corona intrecciata da varii Litterati co'fiori de'loro ingegni, per coronar di nuovo il molto rewerendo padre Giacomo Lubrani..., Apresso Antonio Bosio, Wenecja 1675.

Ziegelbauer M., Historia rei literariae ordinis s. Benedicti in IV. partes distributa..., Sumptibus Martini Veith, Augsburd i Würzburg 1754.

dr hab. Joanna Usakiewicz, Uniwersytet w Białymstoku, Katedra Bioetyki i Antropologii Filozoficznej 